\title{
Reconstruction of Lower Extremity Necrotizing Fasciitis with Tibialis Anterior Musculofascial Flap and Skin Graft: A Case Report
}

\author{
Jinhyun Kim (D), Taewoon Kim (D), Seokchan Eun (D) \\ Department of Plastic and Reconstructive Surgery, Seoul National University Bundang Hospital, Seongnam, Korea
}

\begin{abstract}
Necrotizing fasciitis of the lower extremities results in large tissue defects, and most cases require reconstruction using skin grafts or flaps. We describe a 61-year-old man who developed necrotizing fasciitis of the right lower leg and septic shock, following a traumatic injury to his leg. Wound culture yielded methicillin-resistant Staphylococcus aureus. Extensive debridement was performed four times along with the use of appropriate antibiotics. After 2 weeks, physical examination showed an open wound (approximately $30 \times 20 \mathrm{~cm}$ in size) with partial tibial bone exposure. Subsequently, the patient underwent successful reconstruction using a tibialis anterior musculofascial flap and splitthickness skin grafting. The tibialis anterior muscle was bihalved and pivoted to cover the exposed bone surface. The patient was without pain and was able to successfully perform daily activities at the 15-month follow-up. This case report highlights the utility of a bihalved tibialis anterior musculofascial flap for lower extremity reconstruction, particularly in patients for whom free flap transfers are unviable.
\end{abstract}

Keywords: Fasciitis, necrotizing; Surgical flaps; Reconstructive surgery; Wound infection

\section{서 론}

괴사성 근막염(necrotizing fasciitis)은 표재성 근막의 감염에 의해 빠르게 진행되며 광범위한 연부조직의 괴사를 특징으로 하는 중증 감염성 질환이다. 외상이나수술 이후에도 발생 가능 하며 연부 조직이 있는 신체 어디에서든 발생할 수 있으나, 사지에서 가장 흔하게 발생하는 것 으로 알려져 있다[1]. 괴사성 근막염은 국소 감염으로 시작되어 단시간 내에 근막 깊이까지 침 투할 수 있으며, 평균 사망률은 $25 \%$ 에서 $35 \%$ 에 이르고, 치료가 지연되어 적극적 변연절제술 (debridement)이 시행되지 않을 때에는 사망률이 $70 \%$ 에서 $100 \%$ 까지 증가할 수 있다[2,3]. 괴사 조직의 변연절제 후 남은 결손 부위의 창상 바닥(wound bed) 혈류 상태가 양호한 경우, 피부 이 식으로 덮는 것을 고려할 수 있다[4]. 하지만 뼈의 노출이 있거나, 창상 바닥의 혈류가 좋지 않으 면치유의 지연으로 인해 기능적으로나 미용상으로 좋지 못한 결과를 낳을 수 있다.

본 증례 보고에서는 하지에 발생한 괴사성 근막염 환자에서 전경골근-근막피판(tibialis anterior musculofascial flap)과 부분층 피부 이식(split-thickness skin graft)을 이용하여 효과적으 로 결손 부위의 재건을 시행한 사례를 소개하고자 한다. 본 연구는 헬싱키 선언의 원칙을 준수 하였으며, 환자에게 사진 촬영 및 사용에 대한 동의서를 취득하여 수행되었다.

\section{증례}

특이 과거력 없는 61 세 남성 환자가 우측 하지를 철제 구조물에 찔린 지 약 5 일 뒤부터 발적과 통증을 동반한 염증 소견을 보였다. 이에 환자는 인근 정형외과 의원에 내원하였으며, 연조직 염 진단 하에 세파제돈(cefazedone) 항생제 치료를 4일간 받았다. 그러나 창상은 호전되지 않았

\section{Case Report}

Received: June 30, 2021

Revised: August 19, 2021

Accepted: August 20, 2021

Corresponding author:

Seokchan Eun, M.D., Ph.D.

Department of Plastic and Reconstructive Surgery, Seoul National University Bundang Hospital,

82 Gumi-ro 173beon-gil, Bundang-gu, Seongnam 13620 , Korea

Tel: +82-31-787-7223

Fax: +82-31-787-4055

E-mail: seokchan.eun@gmail.com

This is an Open Access article distributed under the terms of the Creative Commons Attribution Non-Commercial License (https://creativecommons.org/licenses/by-nc/4.0/) which permits unrestricted non-commercial use, distribution, and reproduction in any medium, provided the original work is properly cited.

(c) 2021 Korean Wound Management Society 
Kim J et al.

Tibialis anterior musculofascial flap
JWMR

제술을 시행하였으며, 이후에도 약 2 주에 걸쳐 총 4 회 변연절제술을 시행하며, 환자의 전신 컨디션은 서서히 호전되었다. 항생제로 사이프 로플록사신과 반코마이신을 투약하던 중, 호중구감소증이 발생하여 반코마이신을 테이코플라닌(teicoplanin)으로 변경하였다. 환자가 응 급실에 내원한지 약 1 달 경과 후, 병변에서는 더 이상 균이 동정되지 않았으며, 혈액 검사 결과도 C-반응단백 $3.5 \mathrm{mg} / \mathrm{dL}$ 과 백혈구수 8,600 cells $/ \mathrm{mm}^{3}$ 으로 호전되었고, 창상에서 염증성 삼출물이 나오지 않았 다. 감염내과 상의 하에 기존 항생제 투여를 중단하였고 박트림(Bactrim)만 투여하였으며, 우측 하지의 광범위한 연부조직 결손에 대해 재건 수술을 시행하기로 하였다. 하지의 창상은 무를 부위에서 발목 부위까지 앞쪽 다리 전반부에 걸쳐 있었고 결손 부위의 크기는 약 30 $\times 20 \mathrm{~cm}$ 에 달하였다(Fig. 1).

재건에 앞서 변연절제술이 시행되었다. 환자를 앙와위 자세로 눕힌 채, 피부 및 일부 괴사된 근막을 포함한잔존 괴사조직을 모두 제거하 였다(Fig. 2). 변연절제술 시행 후, 초기 병변에서 궤양이 있던 전경골 의 중간 약 $1 / 3$ 부위가 $20 \times 4 \mathrm{~cm}$ 정도 노출이 되었는데, 이 부위를 덮 어주기 위해 괴사성 근막염으로부터 비교적 안전하였던 전경골근근막 피판을 활용하기로 하였다. 먼저 전경골근 내측(medial)에 위치 하는 전경동맥의 천공지(anterior tibial artery perforator) 3 개를 도플 러를 활용하여 찾은 뒤, 이를 혈관경으로 하는 “ㄷ”자 모양의 전경골 근-근막피판을 디자인하였으며, 이어서 전경골근의 외측(lateral)에서 부터 근육을 이등분(bihalving)하여 피판을 거상하였다. 피판 거상 시 근육에서 신선한 피가 나오는 것을 확인하였다. 이후 거상한 피판 의 내측을 축으로 하여 피판을 회전문처럼 회전시켜 뼈가 노출된 부 위를 덮어주었고(Fig. 3), 이를 긴발가락굽힘근(flexor digitorum longus muscle)에 고정해주었다(Fig. 4). 피부의 결손에 대해서는 반대 측 허벅지에서 채취한 부분층 피부를 활용하여 덮어주었고 이후 압박 드레싱을 가하였다(Fig. 5).

피판과 이식된 피부는 합병증 없이 모두 잘 생착되었다. 수술 후 15 개월 뒤마지막 외래 방문 시 환자는 발목 관절 운동 범위 제한 및 보행 장애가 없었으며, 특별한 불편감 없이 혼자서 일상생활이 가능하였다 (Fig. 6).

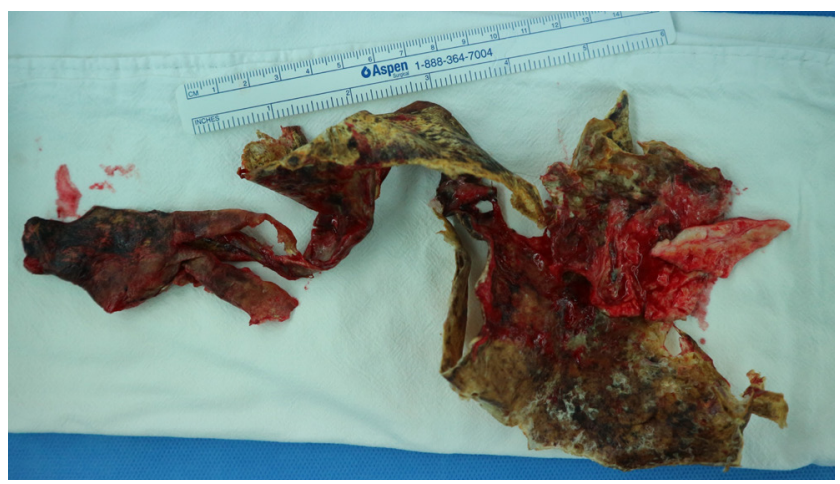

Fig. 2. Intraoperative photograph of the necrotic tissues. Extensive debridement was performed including excision of necrotic skin, fascia and muscle tissue. 
Kim J et al.

Tibialis anterior musculofascial flap

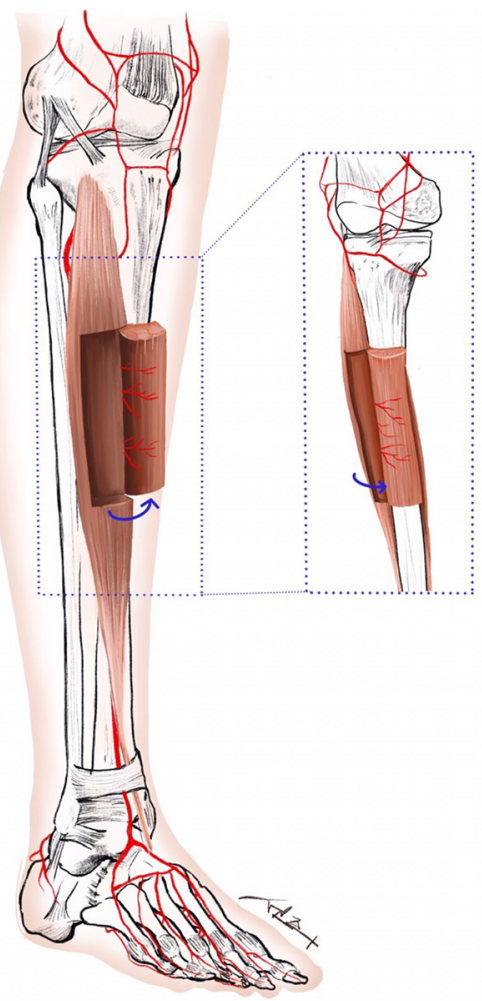

Fig. 3. Schematic illustration of our surgical method. Three perforators for the tibialis anterior musculofascial flap were identified along the pivoting axis using Doppler ultrasound.

\section{고 찰}

괴사성 근막염은 여러 차례의 변연절제술을 해야 하며, 문헌 고찰에 따르면 약 $22 \%$ 가 사지 절단을 수반하기도 한다[5]. 적절한 변연절제술 과 안정적인 재건은 기능의 보존과 이차 감염의 방지를 위해 필수적 이다. 임상적으로 발열, 부종의 빠른 진행 및 비함요부종(non-pitting edema), 짙은 적색의 경화(induration) 및 수포 등이 중요한 징후이며, 이어서 피부의 괴사로 이어진다[1,3,6]. 본 증례의 환자도 병변 부위의 범위가 갑자기 넓어졌고 피부가 변색되었으며 수포가 발생하였다고 호소하였다. 일반적으로 피부의 괴사가 발생하기 전까지 환자는 임상 적으로 보이는 상태에 비하여 심한 통증을 호소하므로 진단에 어려 움을 겪기도 한다[6]. 괴사성 근막염은 비스테로이드성 소염제(nonsteroidal anti-inflammatory drug, NSAID) 혹은 스테로이드의 사용 력, 최근 수술력, 간경화, 악성 종양, 면역 저하, 비만, 당뇨 등과 연관되 어 있으며, 특히 당뇨병을 가장 흔히 동반한다[7,8]. 정확한 기전이 알 려져 있지는 않으나, 이러한 요인들이 호중구의 기능을 저하시키고 사이토카인(cytokine) 분비를 변화시켜서 세균감염을 빠르게 진행하 도록 만든다고 알려져 있다[9]. 통증의 경감과 해열을 목적으로 사용 한 NSAID가 염증 징후를 가리는 효과를 나타내어 진단을 늦추는 것 또한 병변의 진행을 야기하는 인자로 작용한다[10]. 또한, 흔하지는 않 지만 본 증례에서와 같이 기저 질환 없는 건강한 성인들에서도 일상

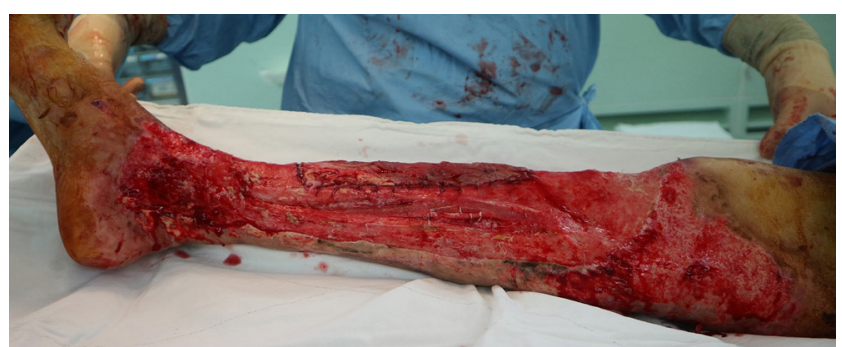

(A)
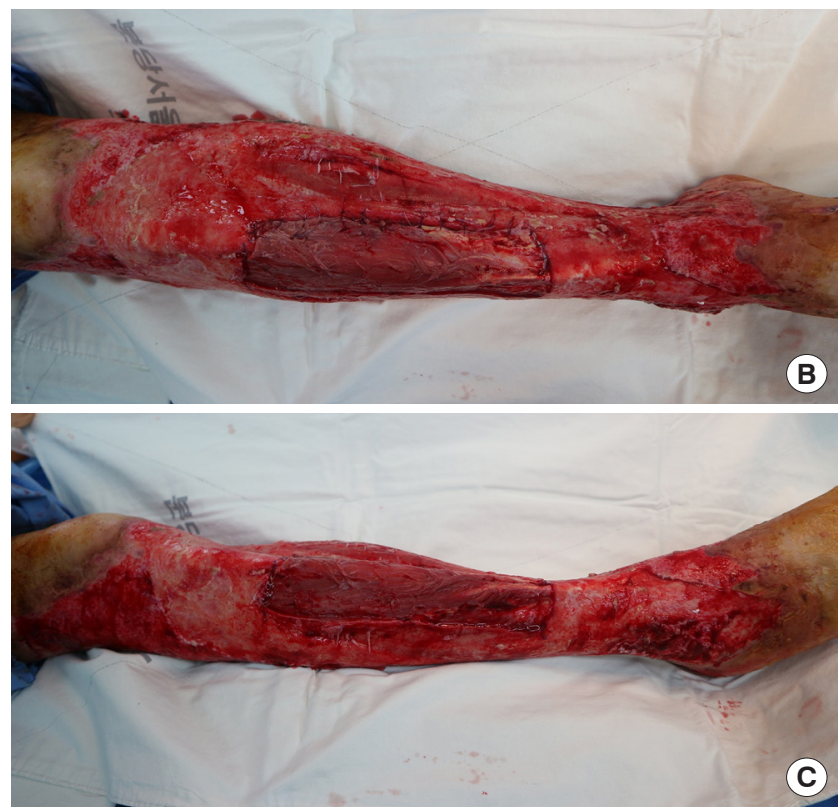

Fig. 4. Intraoperative photographs after pivoting the tibialis anterior musculofascial flap. After debridement, approximately $20 \times 4$ $\mathrm{cm}$ of the mid portion tibial bone was exposed. A tibialis anterior musculofascial flap based on medially located anterior tibial artery perforators was elevated. The flap was then pivoted over to the exposed tibial surface to cover the defect, and was fixated on the soleus muscle. The photographs show the medial (A), anterior (B), and lateral (C) view of the right lower leg.

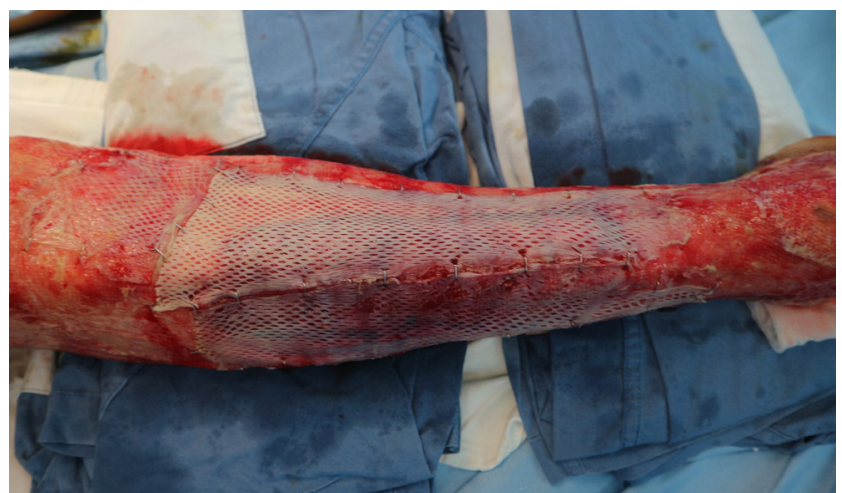

Fig. 5. Immediate postoperative photograph after inset of the skin graft. Split-thickness skin harvested from the contralateral thigh was used for coverage of the skin defect. 

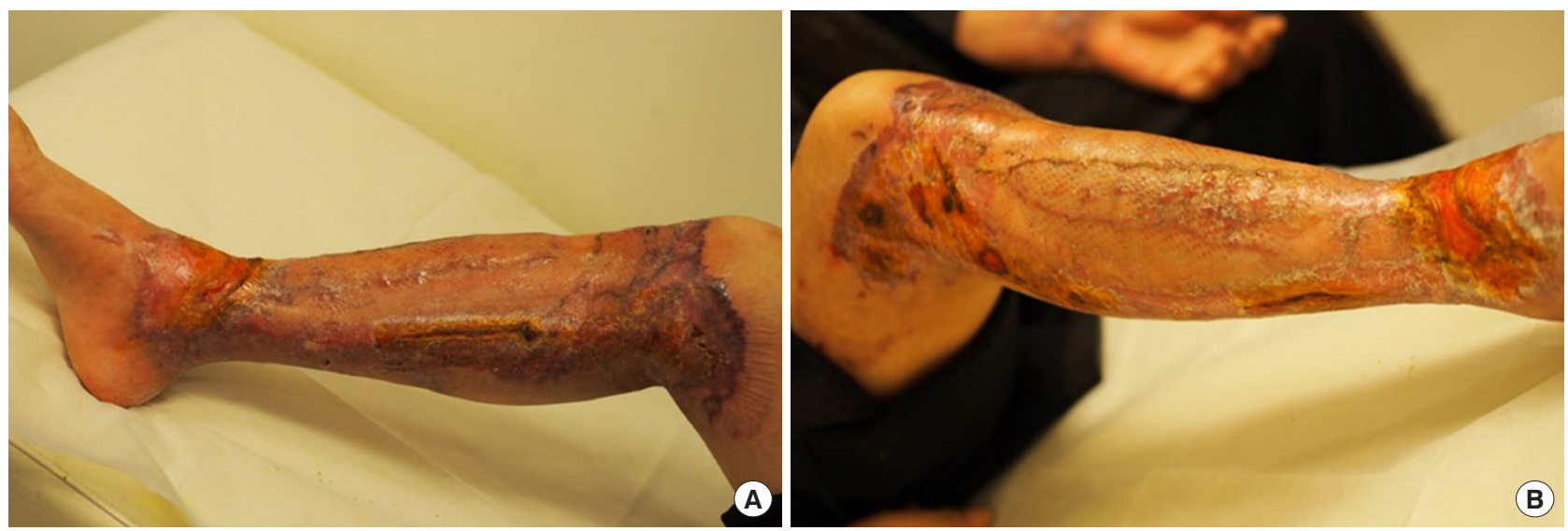

Fig. 6. Postoperative photographs of the patient at 15 months. At postoperative 15-month follow-up, the patient was free of pain without any limitation of movements and was able to carry out daily activities without trouble. The medial view (A) and the anterolateral view $(B)$ are shown.

생활 중 입은 외상이나 화상이 괴사성 근막염으로 발전할 수 있다[1]. 많은 경우 피부 이식만으로도 괴사성 근막염으로 인한 결손의 재건 이 가능하지만, 그렇지 않은 경우 유리피판을 이용하여 효과적으로 재건이 가능하며, 이에 대한 사례 보고는 과거에 많이 있었다[11-13]. 그러나 괴사성 근막염 환자들은 당뇨, 비만, 흡연력 등 유리피판의 성 공률을 저하시킬 수 있는 동반 질환이나 위험 인자를 가진 경우가 많 고, 특히 생체 징후가 안정되지 않은 환자에게 장시간의 수술은 그 자 체만으로도 부담이 될 수 있다. 또한, 광범위한 염증 반응은 이차적으 로 혈관에 손상을 가할 수 있음으로, 유리 피판술을 시행하면서 함께 고려해야 한다고 할 수 있다[13]. 이러한 환자들에서는 비복근 피판 (gastrocnemius flap) 혹은 가자미근 피판(soleus flap)을 활용한 국소 피판술도 시행 가능하며, 특히 본 사례와 같이 전경골 중간 $1 / 3$ 지점 에 결손 부위가 위치한 경우 효과적인 재건 방법이 될 수 있다[11,14]. 하지만 이 역시 공여부에 추가적인 흉터가 남게 되며, 보행 장애를 일 으킬 가능성이 있다.

저자들은 이미 개방되어 있는 결손 부위 내에서 재건을 효과적으 로 시행할 방법을 모색하였고, 괴사 범위로부터 비교적 안전하였던 전경골근을 이등분하고, 거상한 피판을 회전문처럼 피벗(pivot) 시키 는 방법을 사용하였다. 본 증례에서 활용한 전경골근-근막피판이 동 반 질환이나 위험 인자를 가진 환자의 정강 부위의 재건에 있어 공여 부합병증 및 기능 저하를 최소화하면서, 비교적 간단한 술식으로 사 용될수 있으리라 생각한다.

\section{이해관계}

이 논문에는 이해관계 충돌의 여지가 없음.

\section{ORCID iDs}

Jinhyun Kim

https://orcid.org/0000-0001-5621-3628
Taewoon Kim

Seokchan Eun

https://orcid.org/0000-0001-7581-4832

https://orcid.org/0000-0003-4372-6955

\section{References}

1. Trent JT, Kirsner RS. Diagnosing necrotizing fasciitis. Adv Skin Wound Care 2002;15:135-8.

2. Hakkarainen TW, Kopari NM, Pham TN, et al. Necrotizing soft tissue infections: review and current concepts in treatment, systems of care, and outcomes. Curr Probl Surg 2014;51:344-62.

3. Lancerotto L, Tocco I, Salmaso R, et al. Necrotizing fasciitis: classification, diagnosis, and management. J Trauma Acute Care Surg 2012;72:560-6.

4. Cho YS, Yang HT, Yim H, et al. Necrotizing fasciitis following a small burn. J Korean Surg Soc 2010;79:71-4.

5. Nazerani S, Maghari A, Kalantar Motamedi MH, et al. Necrotizing fasciitis of the upper extremity, case report and review of the literature. Trauma Mon 2012;17:309-12.

6. Kojic M, Mikic D, Nozic D, et al. Streptococcal necrotizing fasciitis with toxic shock syndrome and rapid fatal outcome. Srp Arh Celok Lek 2015;143:476-9.

7. Cheng NC, Tai HC, Chang SC, et al. Necrotizing fasciitis in patients with diabetes mellitus: clinical characteristics and risk factors for mortality. BMC Infect Dis 2015;15:417.

8. Anaya DA, McMahon K, Nathens AB, et al. Predictors of mortality and limb loss in necrotizing soft tissue infections. Arch Surg 2005;140:151-8.

9. Chen PC, Tsai SH, Wang JC, et al. An elevated glycemic gap predicts adverse outcomes in diabetic patients with 
necrotizing fasciitis. PLoS One 2019;14:e223126.

10. Aronoff DM, Bloch KC. Assessing the relationship between the use of nonsteroidal antiinflammatory drugs and necrotizing fasciitis caused by group A streptococcus. Medicine (Baltimore) 2003;82:225-35.

11. Somasundaram J, Wallace DL, Cartotto R, et al. Flap coverage for necrotising soft tissue infections: A systematic review. Burns. 2021 Feb 3 [Epub]. https://doi.org/10.1016/j. burns.2021.01.005.

12. Lee YK, Lee M. Treatment of infected Achilles tendinitis and overlying soft tissue defect using an anterolateral thigh free flap in an elderly patient: a case report. Medicine (Baltimore) 2018;97:e11995.

13. Gawaziuk JP, Liu T, Sigurdson L, et al. Free tissue transfer for necrotizing fasciitis reconstruction: a case series. Burns 2017;43:1561-6.

14. AlMugaren FM, Pak CJ, Suh HP, et al. Best Local Flaps for Lower Extremity Reconstruction. Plast Reconstr Surg Glob Open 2020;8:e2774. 